\title{
VALORIZACIÓN DE LA RAÍZ DE YACÓN: OBTENCIÓN DE UN JARABE RICO EN FRUCTOOLIGOSACÁRIDOS
}

\section{Diana Lizeth López Torrez}

\section{RESUMEN}

El yacón (Smallanthus sonchifolius P\&E) es un una raíz tuberosa de origen andino que posee un alto contenido de fructooligosacáridos (FOS), los mejores prebióticos conocidos. Se encuentra subutilizada tanto en Bolivia como en el resto de los países productores y esta situación podría cambiarse a través de su industrialización. En ese sentido, a partir de la raíz de yacón, se estudió en laboratorio la obtención de un jarabe concentrado, rico en FOS. Se determinaron las variables críticas y las condiciones óptimas del proceso, lográndose un rendimiento del $95 \%$ de los FOS. A partir de estos resultados, se diseñó una planta para la producción anual de 1000 TM de jarabe con 45\% de FOS, al año. El producto final sería destinado principalmente a un mercado industrial, con un precio de $2,7 \$ \mathrm{US} / \mathrm{kg}$ de jarabe. Para la planta se calculó una TIR de $42 \%$.

Palabras Clave: Valorización, Subutilización, Yacón (Smallanthus Sonchifolius), Fructooligosacáridos (FOS), Fructanos. 